\title{
Research on the Impact of We Media Marketing on Brand Communication
}

\author{
Yingqiang $\mathrm{Wu}$, Zeping Tong* \\ College of management \\ Wuhan University of science and technology \\ Wuhan, China \\ Email: Tongzp76@126.com (Zeping Tong)
}

\author{
Chaojie Liu, Yuchuan Xiao \\ College of management \\ Wuhan University of science and technology \\ Wuhan, China
}

\begin{abstract}
The purpose of this paper is to investigate the impact of the We Media marketing on its own brand communication. By briefly describing the main content and development of We Media, we will introduce its influence as a new type of marketing tool for the enterprise, and further analyze the advantages and problems faced by We Media. This article believes that the We Media marketing launched by enterprise will help spread enterprise's own brand. This paper sums up the problems faced by enterprise in launching We Media marketing, helps enterprises to summarize issues in the media marketing process, and analyze their own shortcomings in a timely manner. At the same time, this paper gives corresponding solutions and suggestions when summarizing the problems, which will help companies to solve related problems.
\end{abstract}

Keywords-We Media; Marketing; Social networking; Brand communication

\section{INTRODUCTION}

With the rise of the mobile Internet era, a series of mobile social media such as Weibo and WeChat have formed a huge social network of people's lives. Social sharing of content as people access to corporate brand and product information, a major mainstream channel, the impact of consumer decisions should not be underestimated. For today's smarter, more suspicious, socially connected consumers, traditional marketing is losing a bit of its impact. Consumers are no longer blindly led by businesses and passively accept advertising, but proactively collect all kinds of relevant information. Hard-copy ads released by businesses that disrupt consumer thinking or sensory experiences are increasingly disgusted and contradictory. And some share in the way consumers like, both associated and valuable content more easily accepted by consumers and dissemination. As a result, We Media marketing, which shares valuable content with We Media, delivering product or brand information, is gaining traction.

This article draws on We Media's core concepts and outlooks to shed light on its impact on the business as a new type of marketing tool, analyzes the strengths and issues of We Media marketing and explores the impact of We Media marketing on its own brand communication.

\section{LITERATURE REVIEW}

With the advent of the mobile Internet era, social networking sites have become an indispensable communication tool for people, and people have formed their own social networks. Many companies in this wave open We Media mode, vigorously develop fans, the use of fans to expand the scope of communication. Kozinets (1999) found that fans have more emotional connections with the company or brand and are more active in corporate marketing activities [1]. Such as the Chinese apples known as millet phone, fan propaganda shop. According to the study by scholar Ma Shuning (2014), interaction is an important factor affecting brand loyalty. Positive interaction between enterprises and fans helps to enhance brand loyalty [2].

Lipsman, Mudd, Rich, \& Bruich (2012) point out that while fans deliver more value to their business, they require less for economic rewards [3]. Jansen, Zhang, Sobel and Chowdury (2009) pointed out that the advent of social media has changed the communication mode between enterprises and consumers Enterprises can interact directly with consumers in the media and within consumer groups [4]. Bakshy, Hofman, Mason and Watts (2011) mentioned that recommendation and interaction are the inner core of the social networking media business and the goal of businesses that run We Media marketing [5]

In the field of management, some scholars compare the concept of paid media, free media and We Media, and their impact on the brand. Lovett et al. (2012) found that in the three media about Tip activation for consumers to remember, to persuade consumers and enhance the role of entertainment brands to evaluate after, compared to the other two media, We Media influence but can not be ignored, it is self-contained, low cost, accurate to the audience, versatile and sustainable[6]. Bacile (2014) proposed that We Media be more participative and personalized, that the brand is marketed and spread in the personal media, and that consumers are invited to participate in co-creation marketing strategies. This will give consumers a sense of customization, help them to improve their attitudes toward marketing communications and their willingness to buy, and effectively reduce their risk perception of marketing activities [7]. Baetzgen (2013) conducted a research study of We Media and analyzed the factors influencing We Media's success. One of the most important content-centric factors is 
the most crucial factor for We Media to create content and win traffic [8].

Hardey (2011) proposed that content marketing is a way to market and distribute content that is both engaging and engaging with diverse audiences to attract and retain customers and use content as a communication tool to influence existing and potential customers [9]. We Media content marketing is based on the social media content marketing, the content of the media attributes were limited accordingly. Wang Jiaying (2011) pointed out in his research on We Media that the emergence of We Media has diversified the information and made it possible for individuals to disseminate information, changing the centrality of discourse monopolization in the traditional media [10]. Businesses can reach their target customers directly through We Media and no longer need third-party media. Therefore, the enterprise We Media content marketing means that the enterprise conducts personalized, interactive and equal information communication with consumers through We Media (such as Weibo, WeChat, etc.), and autonomously creates and delivers relevancy and value content in the process

Liana Li Evans (2010) found that in order for social marketing to succeed and be effective, companies must research social media marketing, develop strategic planning, execute programs, build teams, and socialize, initiate conversations, and measure[11]. Tang Xingtong (2012) pointed out that in the social media, the marketing and communication of enterprises has undergone tremendous changes, will pay more attention to the user's participation and reputation, and emphasize the user's interaction [12]. The traditional marketing advertising model is one-sided information output of enterprises, seldom emphasize user experience and feedback. Social marketing focuses on customer's reputation, customer's communication and brand's reputation, and ultimately results in word-of-mouth marketing based on social media platform and continuous brand reputation.

After reviewing and reviewing We Media and marketing related literature and materials, we found that enterprises have good interaction with consumers in We Media and can help improve brand loyalty. Compared with the traditional media marketing, We Media meets the interest and information acquisition habits of the new generation of consumers, which can provide more effective means and methods for brand marketing. It is very necessary to adopt We Media marketing in line with the trend of the times. At the same time, the use of We Media marketing companies should be based on their own circumstances, the implementation of effective We Media marketing strategy to increase brand communication and expand its influence.

\section{CONCEPT AND PRospect OF We MEdia MARKETING}

With the rapid development of online media, new media technologies are rapidly developing and updating. As an emerging media platform, We Media is forming a force that relies on the spread of the Internet to influence all aspects. As a new flat information delivery platform, We Media has played its own role in information delivery, commercial marketing and customer service. We Media is characterized by a high degree of personalization, focus on the interconnection between users, pay more attention to user experience. For the enterprise, in the era of We Media, the development of the enterprise is facing new opportunities and challenges. In order to establish a good corporate image and maintain the brand and reputation of the enterprise, the enterprise must change its original brand communication strategy to adapt to the new environment. How successful We Media marketing is determined is something companies must stand out and do when they stand out in the age of We Media.

\section{A. The Concept and Characteristics We Media}

The concept of "We Media" first appeared in Dan Gillmor's definition of "News Media 3.0" in 2002. "1.0" refers to traditional media or old media, "2.0" refers to new media, and "3.0" refers to We Media. The media center of the American Journalism Institute published a very rigorous definition of "we media" in a July 2003 "we media" study co-sponsored by Shayne Bowman and Chris Willis. We Media is the mass media through the digital technology to strengthen and connect with the global knowledge system, a way to begin to understand how the general public to provide and share their own facts, the transmission of their own news. "We Media, also known as "personal media," refers to the communicators of privatization, common people, generalization and autonomy, the general term for new media that conveys normative and non-normative information to the unspecified majority or a single individual by means of modern informatization. Including BBS, blog, community space, podcast, WeChat circle of friends, is a personalized, interactive, multi-media forms of information dissemination carrier.

The scholar Luo Bin (2009) systematically studied the development of online media. He believes We Media has made network information more diversified and more rapid. The development of We Media has become a trend of online media [13]. We Media era overthrew the traditional media discourse hegemony, people no longer passively accept the message, but by the "bystander" into a "participant", the media is no longer a symbol of supremacy. We Media can quickly spread the message to a wide range of network recipients who can quickly respond to the message dissemination. There is no distance between We Media and the audience. We Media has become the best place for the general public to express individuality and express themselves, and its powerful interaction is beyond the reach of any traditional media. Scholars Zhang Meiling and Luo Yi (2011) summarized three characteristics of We Media in the study: audience liberalization, content fragmentation and rapid and rapid dissemination [14]. Dai YuMei (2011) compared We Media with other media platforms. The author thinks We Media appears to have the function of real-time interaction with the information of the media, and has 
optimized the traditional methods of information dissemination, being more personalized and technical [15].

\section{B. The Concept of We Media marketing}

When We Media possessed the basic value of communication, it had the value of influence and the value of marketing, which formed the complete value chain of media market. The marketing value of We Media was recognized and applied by the market. In the concept of market economics, the marketing model is more about a system than a simple marketing or strategy. The rapid growth of We Media has brought about tremendous changes in communication, and these changes in turn affect the new marketing methods. Using We Media for corporate marketing is an opportunity for businesses to take the opportunity to promote their brands and products and preserve their corporate image. The new media needs new marketing tools to adapt to corporate marketing

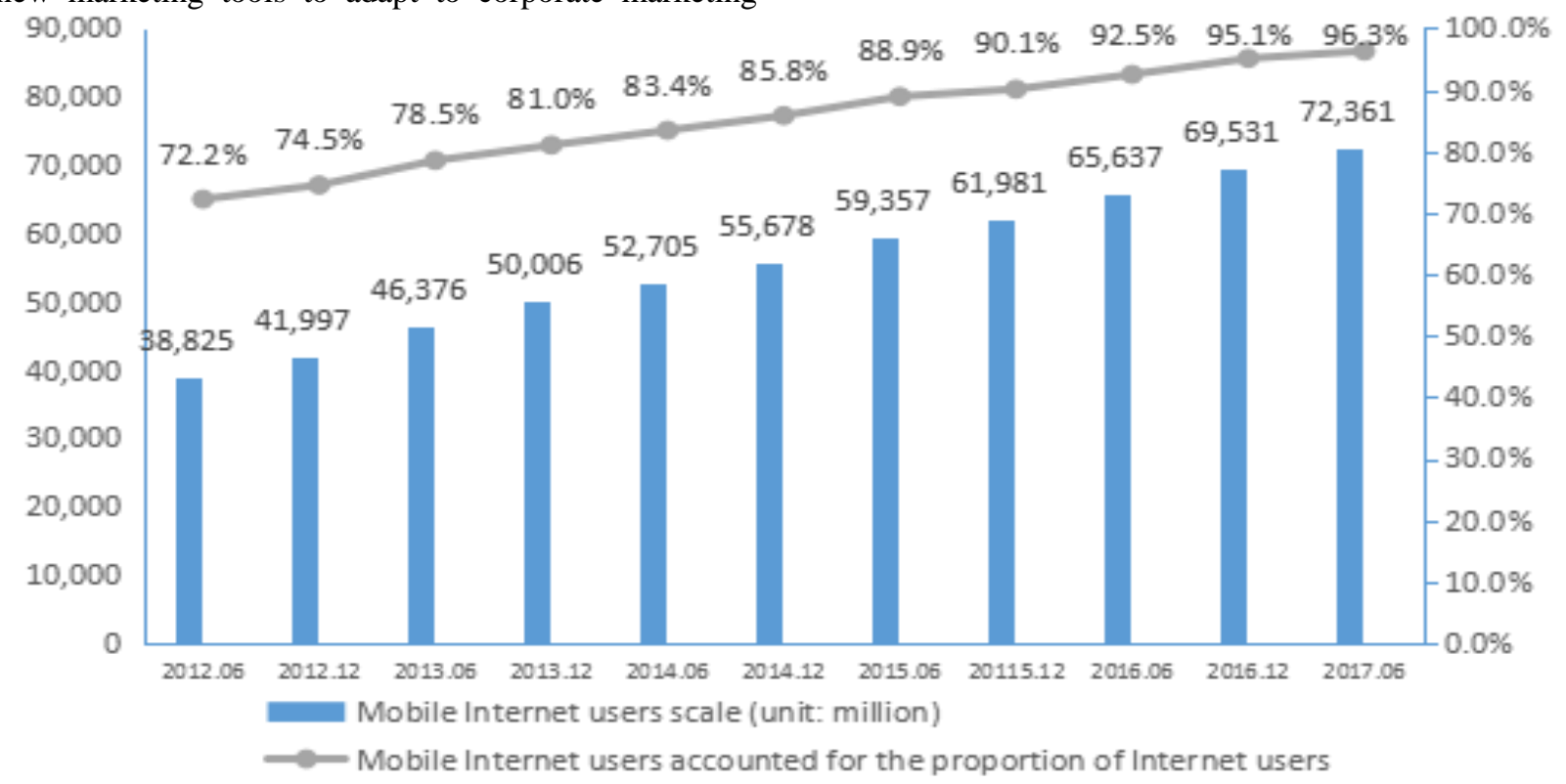

Fig. 1. The scale of china mobile phone internet users and their proportion to internet users

As can be seen from Figure 1, as China's mobile Internet has entered a period of steady development, all kinds of integrated applications continue to integrate functions such as social networking, information services, transportation, travel and livelihood services to create an integrated service platform and expand its service scope and influence. More and more activities in the new media environment. Unlike traditional media, SMEs can also participate in marketing with We Media at low cost, and can combine their own characteristics and achieve good results.

\section{The Development Prospects of We Media marketing}

According to the "40th Statistical Report on Internet Development in China" released by the China Internet Network Information Center, as of June 2017, the number of mobile Internet users in China reached 724 million, an increase of 28.3 million from the end of 2016. WeChat circle of friends, QQ space user usage was $84.3 \%$ and $65.8 \%$ respectively; Weibo as a social media, thanks to the celebrity star, reticulation and the media content of the ecological establishment and continuous strengthening of user utilization continued to rise, reaching $38.7 \%$. 
As can be seen from Figure 2, as China's mobile Internet has entered a period of steady development, all kinds of integrated applications continue to integrate functions such as social networking, information services, transportation, travel and livelihood services to create an integrated service platform and expand its service scope and influence. The vigorous development of social networks has weakened the influence of traditional media, and the influence and interactivity displayed by We Media are unmatched by traditional media.

In the context of the rapid development of mobile Internet, the Internet is more and more popular, and the proportion of mobile Internet users is increasing. The development of social networking has provided a huge space for the development of We Media marketing. Therefore, the development prospect of We Media Marketing is very promising with immense influence and interactivity. Enterprises should vigorously develop We Media to adapt to the new environment of We Media marketing and play a significant role in spreading corporate brand, promoting products and maintaining their own image.

\section{THE ANALYSIS OF WE MEDIA MARKETING'S ADVANTAGES AND PROBLEMS}

\section{A. Advantages of enterprise We Media marketing}

Whether through We Online planning online and offline activities, speculation events, or online marketing can bring huge benefits to the enterprise. Businesses not only expanded their product offerings through We Media marketing, promoted awareness and product sales, but also improved their products and services through good interaction with users, effectively maintaining the brand image. In general, businesses have the following advantages through We Media marketing.

\section{1) User advantage}

According to the "40th Statistical Report on Internet Development in China" released by the China Internet Network Information Center, as of June 2017, the national scale of our country has reached 751 million with an Internet penetration rate of $54.3 \%$. Weibo, a typical representative of We Media, has 340 million monthly active users. So in the We Media era, the user base that organizations can deliver through We Media marketing is pretty big.

\section{2) Cost advantage}

Traditional media marketing costs are huge, such as circulation in newspapers and magazines, TV broadcast ratings, etc., which cost tens of thousands of marketing dollars. New media marketing is a business strategy of realizing soft infiltration of enterprises in the form of new media (such as WeChat and Weibo). Usually, new media and consumer media are used to make consumers agree with certain concepts, views and analysis ideas. So as to achieve the purpose of corporate brand promotion, product sales, the cost is much less than the traditional media marketing. This undoubtedly greatly reduces the cost of marketing and brings many new opportunities to SMEs.

\section{3) Interactive advantage}

Taking the Weibo platform as an example, each person is both a communicator and an audience. The two roles are staggered, which greatly improves the interaction of exchanges. Enterprises can use this kind of interactivity to strengthen guidance for target users. In the meantime, companies can build a link with users who can understand the company's information, feedback needs and problems; and companies can improve the product and quality through user feedback.

\section{B. The Problems of We Media marketing}

We Media Marketing in China started late, the marketing level is uneven, generally low, is still in the development stage, there are some problems in the development process.

\section{1) Lack of professional management and operation personnel}

At present, one of the reasons many businesses do poorly in new media marketing is the lack of professionals. Today, the staff responsible for corporate new media operations are uneven and mostly lack specialized knowledge and experience. Mostly by non-professional sales staff or marketing staff parttime operation, the lack of professional departments, job settings, the operation of a lower level.

\section{2) Lack of We Media marketing system planning}

A new marketing approach to new media marketing also requires systematic strategy and tactical planning as a basis and support. We Media marketing in many enterprises lacks systematic strategies and supporting tactics. The We Media marketing campaigns conducted are often unplanned, unprofessional and unsystematic, and can not achieve the desired brand communication effect.

\section{3) Unclear We Media marketing goal positioning}

When many businesses conduct We Media marketing, they do not match the content they publish with themselves, failing to provide fans with good content and services, hinder the growth of fans, not only fail to achieve the desired results, but also damage the corporate image.

\section{4) Inadequate original content led to serious infringement}

Many companies We Media due to staff and cost constraints, less original content. Often, valuable news and information are found on websites and traditional media, reproduced and excerpted, and the majority is easily infringed without permission and without identifying the source.

\section{5) Lack of relevant laws and regulations}

Due to the poor controllability and the random distribution of information, "individual" voice will be released at the same time, it will inevitably make some of the legal and social ethics contrary to the spread of the voice. As for the spread of internet information, up to now, there is not a mature legal document in our country. Although some legal documents on network control have been issued, they still only remain on the management of some websites and are not perfect. 


\section{6) Lack of attention to customer classification}

In the era of We Media, customers also need to be treated hierarchically, because each client is a We Media launch point Whether customers like businesses, likes information published by We Media tools, and whether they relay We We Media information will have some impact on the company's We Media marketing. Businesses in We Media should learn to deal with different levels of customers and adopt different methods to guide different levels of customers and enhance the effectiveness of We Media marketing.

\section{Suggestions for problems faced by We Media marketing}

1) Strengthen the construction of We Media marketing staff system in enterprises

Businesses should change their traditional marketing concepts and value the important role that We Media marketing plays. Establish high-quality marketing team, allocate human resources to achieve specialist management, through Weibo, WeChat, QQ space, etc. We Media way to strengthen the interaction with consumers. At the same time strengthen We Media marketing management, to attract more professionals, enhance the overall strength of We Media marketing team, improve the performance of We Media marketing activities.

2) Strengthen the construction of We Media marketing system planning in enterprises

We Media marketing system planning to do, we must first determine the choice of We Media operating platform, the platform user base to be large. The second to determine the choice of We Media theme, we must meet the company's own brand. The third is to analyze the attributes of fans, in line with the content of fans. Finally, we also plan the time and frequency of push, activity nodes and forms.

3) Clear We Media Marketing Targeting

Positioning should be based on the competitive environment of enterprises and the core demands of enterprises, combined with the core selling point of their own products and willingness to transmit. Let the audience understand the information through the enterprise We Media, access to good content and services, thereby increasing the forwarding volume, so as to achieve the desired results, help to improve the brand communication.
4) Enhance the originality of We Media marketing content

In the We Media marketing, to maintain the originality of their content, for news, hot events in line with their own fields, combined with their own point of view. Good articles must have their own ideas and innovations, so as to enhance the value of the content and provide the audience with highquality content.

5) Establish corresponding laws and implement effective supervision

The improvement of We Media related functions requires the information regulatory authorities to formulate a corresponding set of complete laws and regulations and effective enforcement mechanisms. Enforcing effective regulation, thereby strengthening the regulatory information release, making We Media Marketing steady development in a sound legal environment.

\section{6) Classify the customers of We Media marketing}

For businesses to better manage their customers in $\mathrm{We}$ Media marketing, companies must focus on the grading of customers. Different ways to guide different levels of customers, effective for customer-level delivery of the marketing content of interest, and enhance the effectiveness of We Media marketing.

\section{CONCLUSIONS}

Through the research of this article, we define the core concepts of We Media and We Media marketing, analyze the future of We Media marketing and the advantages of We Media marketing, and analyze the problems we face. This paper argues that We Media Marketing has a prosperous development prospect and has a vast space for development. Through the analysis of the advantages of We Media marketing, we think that the marketing of We Media can help the spread of its own brand. Summarizes the current problems facing enterprises to carry out We Media marketing, help companies in the We Media marketing process to sum up the problem, timely analysis of their own shortcomings. At the same time, this article gives the corresponding solutions and suggestions in the process of summarizing the problems, which helps the enterprises to learn from and solve the related problems.

\section{ACKNOWLEDGEMENT}

This research was supported by the College Students Innovation and Entrepreneurship Training Program under Grant 201610488003. 


\section{REFERENCES}

[1] Kozinets, R. V. (1999). E-tribalized marketing: The strategic implications of virtual communities of consumption. European Management Journal, 17 (3), 252-264.

[2] Ma shunning (2014). Research on Wechat Marketing Communications. MS D Thesis. Dalian: Dalian Maritime University.

[3] Lipsman, A., Mudd, G, Rich, M., \& Bruich, S. (2012).The power of "like": How brands reach (and influence) fans through social-media marketing. Journal of Advertising Research, 52(1).40-52.

[4] Jansen, B. J., Zhang, M. M., Sobel, K., \& Chowdury, A. (2009). Twitter power: Tweets as electronic word of mouth. Journal of the American Society for Information Science and Technology, 60 (11), 2169-2188.

[5] Bakshy, E., Hofman, J. M., Mason W. A., \& Watts, D.J. (2011).Everyone's an influence: Quantifying influence on twitter. In Proceedings of the fourth ACM international conference on Web search and data mining. New York: ACM, 65-74.

[6] Lovett, M. J., \& Staelin, R. (2012). The role of paid and earned media in building entertainment brands: reminding, informing, and enhancing enjoyment. Marketing Science, 35, 142-157.

[7] Bacile, T. J., Ye, C., \& Swilley, E. (2014). From firmcontrolled to consumer-contributed: consumer co-production of personal media marketing communication. Journal of Interactive Marketing, 28(2), 117-133.

[8] Baetzgen, A., \& Tropp, J. (2013). "owned media": developing a theory from the buzzword. Studies in Media \& Communication, 1(2).

[9] Hardey, M. (2011). Generation c content, creation, connections and choice. International Journal of Market Research, 53(6), 749-770.

[10] Wang Jiaying (2011). Try to analyze the postmodernist characteristics of the current network self-media transmission mode in China .Ms D Thesis. Shanghai: Fudan University.

[11] Evans, L. (2010). Social media marketing: strategies for engaging in facebook, twitter \& other social media.

[12] Tang Xingtong. (2012). Social media marketing trends: strategies and methods. Beijing: Tsinghua University Press, 75.

[13] Luo Bin (2009). Web Self Media Research. MS D Thesis. Lanzhou: Lanzhou University.

[14] Zhang Meiling, \& Luo Yi (2011) .Analysis of the Characteristics and Advantages of Self-media Transmission Represented by Weibo. Journal of Hubei Vocational and Technical College, 14 (1), 45-49.

[15] Dai Yimei (2011). The Nature of Media: An Instant Interactive Platform for Information Sharing. Yunnan Social Sciences (6), 172-174.

[16] China Internet Network Information Center (2017). The 40th Statistical Report on Internet Development in China. http://www. cnnic. net. c n/hlwfzyj/hlwxzbg/hlw tjbg/201708/t20170803_69444.htm. 